\title{
Exploring the link between uncertainty and project activities in New Product Development
}

\author{
Lasso, Sarah Venturim; Kreye, Melanie; Daalhuizen, Jaap; Cash, Philip
}

Published in:

Journal of Engineering Design

Link to article, DOI:

10.1080/09544828.2020.1839743

Publication date:

2020

Document Version

Peer reviewed version

Link back to DTU Orbit

Citation (APA):

Lasso, S. V., Kreye, M., Daalhuizen, J., \& Cash, P. (2020). Exploring the link between uncertainty and project activities in New Product Development. Journal of Engineering Design, 31(11-12), 531-551.

https://doi.org/10.1080/09544828.2020.1839743

\section{General rights}

Copyright and moral rights for the publications made accessible in the public portal are retained by the authors and/or other copyright owners and it is a condition of accessing publications that users recognise and abide by the legal requirements associated with these rights.

- Users may download and print one copy of any publication from the public portal for the purpose of private study or research.

- You may not further distribute the material or use it for any profit-making activity or commercial gain

- You may freely distribute the URL identifying the publication in the public portal

If you believe that this document breaches copyright please contact us providing details, and we will remove access to the work immediately and investigate your claim. 


\section{Exploring the link between uncertainty and project activities in New Product Development}

Sarah Lasso ${ }^{a}$, Melanie Kreye ${ }^{\mathrm{a}}$, Jaap Daalhuizen ${ }^{\mathrm{a}}$, and Philip Cash ${ }^{\mathrm{a} *}$ ${ }^{a}$ DTU Management, Technical University of Denamrk, Kgs. Lyngby, Denmark

To cite this article: S. Lasso, M. Kreye, J. Daalhuizen, P. Cash. (2020) Exploring the link between uncertainty and project activities in New Product Development. Journal of Engineering Design; IN PRESS.

DOI: $10.1080 / 09544828.2020 .1839743$

Technical University of Denmark - Diplomvej 372, 2800 Kgs. Lyngby, Denmark pcas@dtu.dk, +45 45254550 


\title{
Exploring the link between uncertainty and project activities in New Product Development
}

\author{
Uncertainty is central to engineering design and New Product Development \\ (NPD). While there has been substantial focus on dealing with uncertainty in \\ technical systems and design information, how engineering designers react to and \\ manage uncertainty is also critical to performance. However, an important gap \\ remains in understanding what activities NPD teams engage in based on the \\ specific uncertainty types they face. This gap is investigated via a conceptual \\ framework detailing four uncertainty types (technical, organisational, resource \\ and market) and three project activities (information, knowledge sharing and \\ representation). Evidence is presented from two engineering design cases with 45 \\ interviews, observations, and secondary data. Based on this, specific links are \\ described between uncertainty type and project activity as follows: technical \\ uncertainty drove representation activity, organisational uncertainty drove \\ knowledge sharing activity, resource uncertainty drove knowledge sharing \\ activity, and market uncertainty drove information activity. These findings are \\ developed into a number of propositional relationships between the four \\ uncertainty types and specific project activities, which form the basis for a \\ number of implications for engineering design research and practice.
}

Keywords: uncertainty, project activity, new product development, product innovation, case study

\section{Introduction}

While successful new product development (NPD) can produce significant payoffs for firms (Evanschitzky et al. 2012), it is also connected to high uncertainty (O'Connor and Rice 2013; Renzi, Leali, and Di Angelo 2017), which makes design support difficult (Borgianni, Cascini, and Rotini 2018) and can lead to NPD failure (Blauth, Mauer, and Brettel 2014). Kreye et al. (2012) define uncertainty as a "potential deficiency in any phase or activity of the process which can be characterized as not definite, not known or not reliable". Uncertainty has a substantial effect on how people act during engineering design work (Cash and Kreye 2018; Christensen and Ball 2017), and can 
negatively impact NPD performance by making activities and decisions more challenging (Blauth, Mauer, and Brettel 2014; Chalupnik, Wynn, and Clarkson 2013; Schmitt, Scheitza, and Groche 2015).

The literature highlights the general importance of managing uncertainty during engineering design and NPD (Behrens 2016; Johnson 2007; Borgianni, Cascini, and Rotini 2018); and in particular there has been a focus on reducing technical uncertainty in the design system (Zimmermann et al. 2017; Benavides and Lara-Rapp 2019) and recorded design information (Suss and Thomson 2012; Stone, Choi, and Amarchinta 2013). However, while a number of studies have suggested means for supporting design decision-making under uncertainty (Jenab, Sarfaraz, and Ameli 2013; Stone, Choi, and Amarchinta 2013), there remains an important gap in understanding how uncertainty is linked to overall design work and the selection of project activities specifically. This connects to studies describing interactions between uncertainty and the activity of individual designers (Cash and Kreye 2018; Christensen and Ball 2017).

The literature on uncertainty in NPD is relatively rich, with prior theoretical development identifying the importance of various uncertainty types (Kokshagina et al. 2016; O’Connor and Rice 2013; Unger and Eppinger 2011). However, the description of overall team activity in engineering design NPD is still relatively disconnected from research at the design cognition level (Cash, Skec, and Storga 2019), where the effects of uncertainty have been more directly studied (Wiltschnig, Christensen, and Ball 2013; Christensen and Ball 2017). Here, project activities define the predominant actions enacted by the project team members during engineering design in order to complete NPD (Cash, Hicks, and Culley 2015). As uncertainty drives people's actions (MacCormack and Verganti 2003; Fixson, Khachatryan, and Lee 2017), a connection between uncertainty types and project activities can be assumed. However, this 
connection has been little studied and links between uncertainty types and project activities remain undefined.

This gap is of critical importance because in order to effectively deal with uncertainty NPD team leaders and engineering designers must be able to: i) identify the specific uncertainty type, and ii) carry out those project activities best suited to its resolution (O’Connor and Rice 2013). Misidentifying the type of uncertainty or taking ill-suited remedial action can have significant negative consequences on project outcomes, including increasing uncertainty, rework, overruns, or project failure (Kreye et al. 2020). Despite this, the relationship between uncertainty types and specific project activities remains ambiguous. While some existing works have focused on individual uncertainty types (e.g. technical uncertainty), the resulting suggestions for project activities vary between studies (e.g. both prototyping (Gassmann and Schweitzer 2014) and organisational decision making (Yao, Jiang, and Liu 2013)). Thus, there is a critical need for in-depth understanding of how different uncertainty types are resolved in complex NPD settings.

The aim of this paper is to connect the literature streams on uncertainty and project activity and empirically answer the following research question: How do uncertainty types drive the selection of project activities in NPD? Insights are presented from two engineering design NPD case studies in a high technology company in the electronics industry. The findings reveal a number of distinct connections between uncertainty types and project activities, which form the basis for extending current theory and provide implications for engineering design practice.

\section{Theoretical Background}

Given the research aim it is necessary to first sketch the typical context of NPD, before describing current understanding regarding uncertainty and project activity. 
New Product Development (NPD) describes a complex, multidisciplinary process that, if successful, creates profit or, if a failure, market loss, and is therefore crucial to a company's survival (Ulrich and Eppinger 2003). In engineering design NPD, performance is determined by the perception and subsequent action of the team (Blauth, Mauer, and Brettel 2014; Jenab, Sarfaraz, and Ameli 2013). Here, amongst a number of drivers, uncertainty perception is considered central (Borgianni, Cascini, and Rotini 2018; Cash and Kreye 2018). Thus, there is a critical link between the uncertainty perceived by the team, their subsequent project activity response, and overall project performance.

\section{Uncertainty in NPD}

In NPD, research on uncertainty has reached a mature state where 'uncertainty multiplicity', i.e. the existence of multiple uncertainty types, is widely accepted (O’Connor and Rice 2013; Kokshagina et al. 2016). O’Connor and Rice (2013) describe the most recent and, to date, most complete model of uncertainty multiplicity, distinguishing four uncertainty types: technical, organisational, resource, and market. These types were defined based on empirical observations in radical innovation, and have also been identified as relevant in the NPD context (Unger and Eppinger 2011). However, there is relatively little description of how the four uncertainty types described by O'Connor and Rice (2013) are resolved through relevant project activities in NPD. Table 1 describes these four uncertainty types including definitions and examples from the current literature. This distinction is used as a conceptual foundation for this research. Importantly uncertainty and its associated types should not be conflated with related phenomena typically encountered in the engineering design context, including volatility, complexity or ambiguity (Mackey 1992; Carleton, Cockayne, and Leifer 2007). Specifically, Bennett and Lemoine (2014) emphasise that 
these different phenomena pose distinct challenges, which demand specific responses.

Thus, this research limits its scope to investigation of uncertainty.

Table 1: Uncertainty types as defined in the NPD literature

\begin{tabular}{|c|c|c|}
\hline $\begin{array}{l}\text { Uncertainty } \\
\text { type }\end{array}$ & Definition & Examples \\
\hline $\begin{array}{l}\text { Technical } \\
\text { uncertainty }\end{array}$ & $\begin{array}{l}\text { The degree to which the } \\
\text { underlying scientific } \\
\text { (technical) knowledge of the } \\
\text { new product is understood and } \\
\text { can be transformed into a } \\
\text { physical product (Hooge et al. } \\
2016 \text { ) }\end{array}$ & $\begin{array}{l}\text { Lack of clarity in product requirements and design } \\
\text { parameters, these are often not completely clear at } \\
\text { the outset and early stages of NPD (Herstatt, } \\
\text { Verworn, and Nagahira 2004) } \\
\text { Lack of knowledge regarding reliability of specific } \\
\text { (new) product part's design characteristics } \\
\text { (Kokshagina et al. 2016) } \\
\text { Unknown interdependencies between product parts } \\
\text { (Sicotte and Bourgault 2008) }\end{array}$ \\
\hline $\begin{array}{l}\text { Organisational } \\
\text { uncertainty }\end{array}$ & $\begin{array}{l}\text { The gap between the } \\
\text { capabilities an organisation } \\
\text { possesses and its needs } \\
\text { (Galbraith 1974) }\end{array}$ & $\begin{array}{l}\text { Internal procedures of an organisation, such as } \\
\text { changes in the strategic commitment to the project, } \\
\text { related to the processes, schedule, and budged of } \\
\text { the NPD project (O'Connor and Rice 2013) } \\
\text { New, innovative and evolving project process } \\
\text { (Frishammar, Floren, and Wincent 2011) }\end{array}$ \\
\hline $\begin{array}{l}\text { Resource } \\
\text { uncertainty }\end{array}$ & $\begin{array}{l}\text { Lack of understanding } \\
\text { regarding the continuity of } \\
\text { resources, being financial or } \\
\text { competence based that can be } \\
\text { critical to the success of the } \\
\text { project (O'Connor and Rice } \\
\text { 2013) }\end{array}$ & $\begin{array}{l}\text { Fluctuations or unavailability of external funding or } \\
\text { capabilities (O'Connor and Rice 2013) } \\
\text { Lack of internal competency within the project } \\
\text { team that is critical to the successful pursuit of } \\
\text { opportunities and are required to seek partnerships } \\
\text { (O'Connor and Rice 2013) } \\
\text { Unexpected shortages in required material or } \\
\text { resources (O'Connor and Rice 2013) }\end{array}$ \\
\hline $\begin{array}{l}\text { Market } \\
\text { uncertainty }\end{array}$ & $\begin{array}{l}\text { The degree to which markets } \\
\text { are defined, including the } \\
\text { customer needs and wants } \\
\text { being understood (Song, } \\
\text { Jinhong, and Di Benedetto } \\
2001 \text { ) }\end{array}$ & $\begin{array}{l}\text { Future use or user group cannot be anticipated } \\
\text { during the development process (Wiener 2018; } \\
\text { Dempster 2006) }\end{array}$ \\
\hline
\end{tabular}

\section{Project activities in NPD}

Research on project activities in NPD, in contrast, is less developed. However, a number of potentially relevant models and conceptualisations have been proposed in the wider engineering design literature (Sim and Duffy 2003; Storga, Andreasen, and Marjanovic 2010; Cash and Kreye 2018). Existing models differentiate three project activities as follows: information, knowledge sharing, and representation (Cash and Kreye 2018). Table 2 presents an overview of these three project activities, again including definitions and examples. Project activities are connected to the predominant 
actions by individual team members (Cash, Hicks, and Culley 2015), which describes

the synthesis of cognition, behaviour, and motivation in an observable phenomenon

(Bedny and Harris 2005). As project activities connect to the specific actions of

individual team members, and are thus driven by the perceptions of these individuals,

they have been logically and empirically linked to uncertainty (Christensen and Ball

2017). However, theoretical and empirical understanding of the relationship between

specific uncertainty types (Table 1) and activities remains undefined. This poses a

critical challenge to NPD team leaders in both identifying and responding to uncertainty

in NPD.

Table 2: Definition of project activities in the NPD literature

\begin{tabular}{|c|c|c|}
\hline $\begin{array}{l}\text { Project } \\
\text { activity }\end{array}$ & Definition & Examples \\
\hline $\begin{array}{l}\text { Information } \\
\text { project activity }\end{array}$ & $\begin{array}{l}\text { Exploitation of objective data } \\
\text { to improve processes or } \\
\text { outcomes (Hult, Ketchen, and } \\
\text { Slater 2004). Is related to } \\
\text { gathering, processing, and } \\
\text { archiving data }\end{array}$ & $\begin{array}{l}\text { Seeking data from sources such as files, books, } \\
\text { internet, documents, journals, and other such } \\
\text { sources (Ulrich and Eppinger 2003) } \\
\text { Action motivated by uncertainty to acquire } \\
\text { objective data to answer specific questions (Cash } \\
\text { and Kreye 2018) }\end{array}$ \\
\hline $\begin{array}{l}\text { Knowledge } \\
\text { sharing project } \\
\text { activity }\end{array}$ & $\begin{array}{l}\text { Actions and interactions in } \\
\text { project teams where they } \\
\text { exchange and integrate } \\
\text { knowledge expressed with } \\
\text { respect to their understanding } \\
\text { and beliefs, linked to } \\
\text { developing shared } \\
\text { understanding (Hult, Ketchen, } \\
\text { and Slater 2004) }\end{array}$ & $\begin{array}{l}\text { Acquiring or exchanging knowledge with others } \\
\text { from the same or different departments in the } \\
\text { company or even from suppliers or customers } \\
\text { (Wiener 2018) } \\
\text { Can be actioned in the form of regular meetings } \\
\text { and training events (Hult, Ketchen, and Slater } \\
\text { 2004), telephone conversations (Davenport, De } \\
\text { Long, and Beers 2014), and email exchanges } \\
\text { (Wasiak et al. 2011) }\end{array}$ \\
\hline $\begin{array}{l}\text { Representation } \\
\text { project activity }\end{array}$ & $\begin{array}{l}\text { Practices by which team } \\
\text { members externalize their } \\
\text { understanding of certain } \\
\text { elements of the product to, for } \\
\text { example, evaluate its physical } \\
\text { attributes in relation to the } \\
\text { NPD goal (Ulrich and Eppinger } \\
\text { 2003) }\end{array}$ & $\begin{array}{l}\text { Prototyping, product mock-ups, and computational } \\
\text { simulation (Fox et al. 1998) } \\
\text { Connects physical and mental simulation, where } \\
\text { an individual tests their understanding by creating } \\
\text { and manipulating external representations } \\
\text { (Christensen and Schunn 2009) }\end{array}$ \\
\hline
\end{tabular}

\section{Conceptual framework}

Bringing together the literature above it is apparent that there is a generally acknowledged link between uncertainty and project activity (Styhre et al. 2010; Blauth, Mauer, and Brettel 2014). This research seeks to connect the uncertainty types (Table 1) 
and project activities (Table 2) currently described separately within the NPD literature. Specifically, the conceptual starting point of this research is the four uncertainty types: technical, organisational, resource, and market uncertainty, and three project activities: information, knowledge sharing, and representation. Building on these established constructs allows this research to focus on elucidating their manifestation and interrelationships in the engineering design context. This framing explicitly positions this research in theory-building mode (Cash 2018; Eisenhardt 1989), focused on 'relationship-building' (Handfield and Melnyk 1998) between the uncertainty types and project activities.

\section{Method}

Given the research question and the need for theory-building (Cash 2018), an in-depth comparative case study approach was adopted, following best methodological practice for this type of theory development (Eisenhardt and Graebner 2007; Handfield and Melnyk 1998; Robson and McCartan 2011, 154). This is suitable for three main reasons. First, case studies are valuable when there is a lack of theory elucidating the researched phenomenon i.e. the relationship between uncertainty types and project activities in this research (Eisenhardt and Graebner 2007; Handfield and Melnyk 1998). Second, case studies are well suited to exploring relationships between constructs when strong predictions or hypotheses cannot be formulated (Noor 2008; Yin 2018). Third, a qualitative approach makes it possible to investigate phenomena that are context specific, and describe key influences and relationships (Yin 2018). This is relevant because uncertainty in NPD projects is contextual (O'Connor and Rice 2013) and requires depth to establish causal relationships in a theory-building mode (Eisenhardt and Graebner 2007). In particular, this is essential to understanding if the specific instances relating to the uncertainty types are conceptually consistent with prior 
descriptions in the literature. Further, a case-based approach has also been used in a number of major prior studies of uncertainty and project activity (O'Connor and Rice 2013; Kreye et al. 2020; Unger and Eppinger 2011), providing a basis for comparison with this work.

When dealing with qualitative case-based research, robustness must be considered in terms of 'analytical generalisability' (sometimes also referred to as 'theoretical generalisability') (Eisenhart 2009, 59; Robson and McCartan 2011, 154), rather than statistical generalisability typical for quantitative studies. This places an emphasis on in-depth description of the phenomena and abstraction via theoretical analysis (Yin 2018). An important approach to achieving such insight is the use of multiple in-depth cases to triangulate results within the case setting (Yin 2018; Eisenhardt and Graebner 2007). Thus, there are two main methodological criteria: i) cases provide access to rich data, which can be analysed in depth (Yin 2018), ii) cases elucidate 'normal' engineering design NPD due to the difference in context from current theory (O’Connor and Rice 2013; Onwuegbuzie and Collins 2007).

\section{Case selection}

Given the criteria above, a purposive 'typical case' sampling approach was adopted (Onwuegbuzie and Collins 2007). Therefore, cases were selected in order to reflect a typical NPD context (Ulrich and Eppinger 2003). Second, the sample must balance the requirements of saturation, triangulation, and in-depth insight (Yin 2018). Thus, following prior works in this context (Marion, Friar, and Simpson 2012), two cases were identified.

In order to fit the NPD context this research identified two cases in a high technology company in the audio industry dealing with consumer electronic products, such as headphones. The audio industry was selected because of its innovative and 
highly competitive nature where the launch and development of new products is crucial for the competitive positioning of companies. The case organisation had around 1200 employees and was part of a larger business with global operations. The two cases focused on the company's two main customer segments. Case A focused on sports equipment, which was marketed directly to consumers. The product was headphones including two wireless earbuds and the charging case. Case B focused on headsets, which were marketed to business customers and dealt with the creation of a modular headset including the headset itself, the controllers, the digital platform and other features. The similar context of the cases within the same company offers a basis for triangulating the findings, building theory, and mitigating observer bias (Yin 2018). Differences between the cases concerned the customer segment and technology and enabled the researchers to examine the uncertainty types and their connection to project activities.

\section{Data collection}

The data were collected via multiple sources (Yin 2018) following best practice (Gibbert, Ruigrok, and Wicki 2008; Yin 2018) as well as prior works in this context (Marion, Friar, and Simpson 2012; Kreye et al. 2020). These included over 40 semistructured interviews, extensive observation at the case company (over four months), project reports, process plans, Gantt charts and other secondary documentation, and further unstructured meetings with all major participants before and after data collection. Observations and unstructured meetings were documented via extensive field notes. Thirty (out of 40 total) team members were interviewed for Case A and 15 (out of 24) for Case B. The difference in number of interviewees between the two cases is based on the difference in the project team size. The interviewees were selected based on their responsibilities in the NPD cases. Follow up interviews were made to achieve 
data saturation. Table 3 lists the interviewees for both cases.

Table 3: Interviewees

\begin{tabular}{|c|c|}
\hline Case A: Sports headphones & Case B: Business headset \\
\hline Project manager 1 & Project manager \\
\hline Project manager 2 & Project manager 2 \\
\hline Project manager 3 & User experience lead \\
\hline Project manager 4 & Software architecture \\
\hline Product manager $1 \S$ & Software developer \\
\hline Product manager 2 & Digital signal processing (DSP) engineer 1 \\
\hline New product manager & Digital signal processing (DSP) engineer 2 \\
\hline Acoustic engineer & Manufacturing test engineer \\
\hline Project manager supporter (manufacturing) & Product commercialization manager 1 \\
\hline Director of the hardware and manufacture test area & Product commercialization manager 2 \\
\hline User experience designer 1 & Industrialization project manager \\
\hline User experience designer 2 & Cloud Project Manager \\
\hline Software developer 1 & Stress monitoring ANC \\
\hline Software developer 2 & Digital business development \\
\hline Digital signal processing (DSP) engineer 1 & System engineer \\
\hline \multicolumn{2}{|l|}{ Digital signal processing (DSP) engineer 2} \\
\hline \multicolumn{2}{|l|}{ Technical lead (in the batteries) } \\
\hline \multicolumn{2}{|l|}{ Software team lead } \\
\hline \multicolumn{2}{|l|}{ Graphical designer } \\
\hline \multicolumn{2}{|l|}{ System engineer } \\
\hline \multicolumn{2}{|l|}{ Technical writer } \\
\hline \multicolumn{2}{|l|}{ Firmware lead } \\
\hline \multicolumn{2}{|l|}{ Antenna designer } \\
\hline \multicolumn{2}{|l|}{ Antenna concepting } \\
\hline \multicolumn{2}{|l|}{ Audio line manager } \\
\hline \multicolumn{2}{|l|}{ Hardware line manager } \\
\hline \multicolumn{2}{|l|}{ Insight team/Marketing manager } \\
\hline \multicolumn{2}{|l|}{ Product commercialization manager 1} \\
\hline \multicolumn{2}{|l|}{ Product commercialization manager 2} \\
\hline Head of product marketing & \\
\hline
\end{tabular}

Interviews were guided by a protocol where interviewees were asked about the challenges encountered in the project and their response to these. This aimed to elicit examples of the activities taken to overcome each challenge. This approach to data collection regarding uncertainty is aligned with the literature on uncertainty (Kreye et al. 2013). The interviews took between 30 and $60 \mathrm{~min}$, were held individually in dedicated meeting rooms, recorded, and transcribed. In addition to the multiple other data sources this enabled the researcher to gather in-depth insights.

\section{Data analysis}

The data were analysed following an iterative and abductive process. The data were 
initially coded inductively based on the emerging themes and topics to identify overall areas of concern. This enabled identification of concern and resolution activities within the cases based on the researchers' understanding of the data. These were then connected to the concept definitions (Tables 1 and 2) to identify the different uncertainty types and project activities. Here, the researchers travelled back and forth between the data and the literature to ensure conceptual validity of these codes. Following this, axial coding was used to identify links between the codes (Miles, Huberman, and Saldana 2014). Here, the researchers again ensured conceptual validity by travelling back and forth between the literature and the empirical data aligned with recommended practice in the field (Miles, Huberman, and Saldana 2014). The preliminary conclusions were presented to the case company to increase the validity of insights and obtain further feedback (Miles, Huberman, and Saldana 2014).

\section{Findings}

Following case study best practice we first outline detailed evidence for the findings in each case (Gibbert, Ruigrok, and Wicki 2008; Eisenhardt and Graebner 2007), before bringing these together in order to suggest theoretical insights (Robson \& McCartan, 2011, p. 154). Overall, the two cases provided detail on all uncertainty types and project activities, as well as supporting saturation and triangulation of findings (Sandelowski 1995).

\section{Case A: Sports headset for consumers}

The aim of the NPD project in Case A was: "to produce a product that can deliver a really nice experience both in what we call cross body and in ear to ear performance. If you imagine that you have some kind of headset that you only wear in one ear then you want to communicate with your phone. (...) that is what we refer to as a cross body 
performance because somehow the signal has to reach from the phone to ear piece and the other way around" (Antenna designer). The novel technical aspects were the use of wireless communication between the earbuds, and a pin-based interface between the earbuds and charging cradle. The project team was divided into functional groups, including "earbud power management, battery, true wireless earbuds, sweat resistance, user experience features, and comfort" (project documentation). Each functional group had specific tasks related to technical specifications. This complemented the project manager whose tasks included: "coordination across streams, weekly reporting to the steering committee" (project documentation).

Case A faced all four uncertainty types as shown in Table 4 (left-hand columns). These uncertainty types were connected to high levels of technological novelty in the product (technical uncertainty), which necessitated new internal development methods (organisational uncertainty). Furthermore, the project team needed to involve an external supplier as the Technical Lead for batteries described: "so the challenge for me was to find the right battery. [And we] ended up having to do a new development together with our supplier.” This external supplier's ability to deliver the required product parts was unknown (resource uncertainty) as was the acceptance of the new product by users (market uncertainty).

The findings further revealed that the project team engaged in specific project activities to address these uncertainty types (see Table 4, right-hand columns), revealing patterns of connection between uncertainty types and project activities. For example, technical uncertainty was resolved via representation project activities while market uncertainty was resolved via information project activities. 
Table 4: Uncertainty types and project activities in Case A

\begin{tabular}{|c|c|c|c|}
\hline $\begin{array}{l}\text { Uncertainty } \\
\text { type }\end{array}$ & Case examples of uncertainty & Case examples of project activities & $\begin{array}{l}\text { Project } \\
\text { activity }\end{array}$ \\
\hline \multirow[t]{2}{*}{$\begin{array}{l}\text { Technical } \\
\text { uncertainty }\end{array}$} & $\begin{array}{l}\text { Use of new technology unknown to the case company: "...the challenge has } \\
\text { been basically that we did not have a true wireless product before this one. } \\
\text { So this puts a lot of questions up in the air in the beginning of the project" } \\
\text { (Antenna designer). For example, the wireless charging cradle for the } \\
\text { product as described by the Acoustic engineer: "the charging cradle turned } \\
\text { out to be a major development obstacle-we have never done anything like } \\
\text { that and we thought it would be pretty simple because it is basically just a } \\
\text { mechanical construction." }\end{array}$ & $\begin{array}{l}\text { Representational simulations and feasibility } \\
\text { studies: "We were trying to make different } \\
\text { antenna concepts. (...) we actually made one } \\
\text { [prototype] which we could use. [We needed] to } \\
\text { have something which we could test in real life. } \\
\text { So it's not just simulation on paper, but we } \\
\text { actually [did the practical testing] to see what } \\
\text { works best." (Antenna concepting) }\end{array}$ & \multirow[t]{2}{*}{$\begin{array}{l}\text { Representation } \\
\text { project } \\
\text { activity }\end{array}$} \\
\hline & $\begin{array}{l}\text { Integration between product parts, including communication between them: } \\
\text { "we thought it would be relatively simple to integrate the feature part that } \\
\text { ensures this connection between the two and it wasn't. There were a lot of } \\
\text { road blocks, a lot of obstacles that haven't been anticipated or seen in the } \\
\text { pre-study. So we thought that we were buying third party technology and } \\
\text { could integrated into this and it would be a relatively simple part of the } \\
\text { development to have that work, and it wasn't." (Product manager) }\end{array}$ & $\begin{array}{l}\text { Simulations: "you build the simplified model, you } \\
\text { simulate [how] the whole [product] and you will } \\
\text { be answering to a lot of questions, can we put the } \\
\text { microphones here, or can we put a dial here." } \\
\text { (Antenna designer) }\end{array}$ & \\
\hline \multirow[t]{2}{*}{$\begin{array}{l}\text { Organisational } \\
\text { uncertainty }\end{array}$} & $\begin{array}{l}\text { Use of new product development process methods with unclear locus of } \\
\text { decision-making control: "we had to figure out who was in charge of [the } \\
\text { specific technologies] and take decisions. The designer has something to } \\
\text { say, mechanics team had, project manager and the user experience, and it } \\
\text { was not easy to close." (User experience designer 2) }\end{array}$ & $\begin{array}{l}\text { Intensive knowledge sharing within and between } \\
\text { functional groups: project steering committee } \\
\text { appointed to "escalation point, approval of } \\
\text { investments, weekly program review" (project } \\
\text { documentation). The task lead of each functional } \\
\text { group then communicated with other team leads } \\
\text { for coordination }\end{array}$ & \multirow[t]{2}{*}{$\begin{array}{l}\text { Knowledge } \\
\text { sharing projec } \\
\text { activity }\end{array}$} \\
\hline & $\begin{array}{l}\text { Rotation of team members: "some people have been working on the product } \\
\text { for a long time, some have just started, some have barely heard about the } \\
\text { product. So people are not on the same page." (System engineer) }\end{array}$ & $\begin{array}{l}\text { Intensive knowledge sharing within functional } \\
\text { groups. "We had between } 5 \text { and } 20 \text { different tasks } \\
\text { to be explored within each functional group. (...) } \\
\text { And there was one person identified being the } \\
\text { lead of that particular task." (Project manager 2). } \\
\text { The task lead was responsible for "coordinating } \\
\text { within team and towards other [functional } \\
\text { groups], planning, and weekly reporting" } \\
\text { (project documentation). These reporting } \\
\text { meetings would serve to discuss methods, } \\
\text { evaluate possibilities in the project, talk about the } \\
\text { feasibility studies, align understanding and } \\
\text { update tasks' status }\end{array}$ & \\
\hline
\end{tabular}




\begin{tabular}{|c|c|c|c|}
\hline $\begin{array}{l}\text { Resource } \\
\text { uncertainty }\end{array}$ & $\begin{array}{l}\text { Product parts were not available at the promised time: "It turns out, just } \\
\text { before they are about to ship, they find out [the product part] doesn't work. I } \\
\text { mean, it has some defects and we cannot use them. Then we have to wait } \\
\text { another } 3 \text { weeks before we can get a new [product part]." (Project } \\
\text { management supporter) }\end{array}$ & $\begin{array}{l}\text { Knowledge sharing with supplier to align } \\
\text { expectations about the product part in terms of } \\
\text { functionality: "we went down and had them go } \\
\text { through the technology road map to show us how } \\
\text { it would work." (Technical team lead) }\end{array}$ & $\begin{array}{l}\text { Knowledge } \\
\text { sharing project } \\
\text { activities }\end{array}$ \\
\hline $\begin{array}{l}\text { Market } \\
\text { uncertainty }\end{array}$ & $\begin{array}{l}\text { Unknown consumer acceptance: "the new aspects of it, actually we could } \\
\text { not really test the acceptance of this concept, like, how do people react to it, } \\
\text { how to sink the product when taking them out, and putting in the charger..." } \\
\text { (User experience designer 2) } \\
\text { Possible competitor products: "when we started [this project] nothing was } \\
\text { happening, we knew of one competitor, now there is } 15 \text { maybe, so a lot is } \\
\text { happening..." (Project manager 1) }\end{array}$ & $\begin{array}{l}\text { Information acquisition about the potential use } \\
\text { context and user interaction: "we have done some } \\
\text { more orientation work in the form of street } \\
\text { interviews and then we have done a deep dive, } \\
\text { through context mapping, and then we did some } \\
\text { ideation and concepting, based on the insights } \\
\text { that were created." (User experience designer) }\end{array}$ & $\begin{array}{l}\text { Information } \\
\text { project } \\
\text { activities }\end{array}$ \\
\hline
\end{tabular}




\section{Case B: Call centre modular headset}

Case B aimed at the development of a platform and an audio electronic product, as explained by Project Manager 1: “...we will develop a new generation for (this specific) product, with a new platform, features and products". It consisted of one project in the fuzzy front end as explained by the same manager: “...we started as a marketing research, what our competitors offer for the customer and we do not want to be outdated ...", but it also used the standard development process in the company. Case B also faced all four uncertainty types (see Table 5, left-hand columns). Here, it was also the technical uncertainty that formed a starting point for many of the other uncertainty types (similar to Case A): However, the technical uncertainty was mainly related to the complexity of the product family that was to be developed. The product would include many new features that would differ between specific products in the product family. This resulted in a complex organisational set-up with many team members and disciplines, as well as high team member rotation (organisational uncertainty). Furthermore, new competencies needed to be developed internally (resource uncertainty). In combination, organisational uncertainty and resource uncertainty meant that valuable resources in terms of staff time were often not available, which caused project delays as the System Engineer described: “(...) some of the feasibilities weren't actually finished as for right now". The project team again engaged in specific project activities to reduce the uncertainty they experienced (see Table 5 right-hand columns). 
Table 5: Uncertainty types and project activities in Case B

\begin{tabular}{|c|c|c|c|}
\hline $\begin{array}{l}\text { Uncertainty } \\
\text { type }\end{array}$ & Case examples of uncertainty & Case examples of project activities & $\begin{array}{l}\text { Project } \\
\text { activity }\end{array}$ \\
\hline \multirow[t]{4}{*}{$\begin{array}{l}\text { Technical } \\
\text { uncertainty }\end{array}$} & $\begin{array}{l}\text { Complexity of the product family: "a family of products is more } \\
\text { difficult because the variants take a lot of time, and sometimes } \\
\text { it's hard to focus on one product when you need to think about } \\
\text { the whole big picture" (Manufacturing test engineer) }\end{array}$ & $\begin{array}{l}\text { Prototyping: "We are trying to get this platform running in } \\
\text { real time, and see how it works, try it out and get experience } \\
\text { with the system (...) It is not working as intended, we are } \\
\text { trying to understand. At first it works when you put [one } \\
\text { component] in a certain way. But when you put [it in a } \\
\text { different way], it actually doesn't work, so it's a tuning } \\
\text { thing." (Digital signal processing engineer 2) "[And now] } \\
\text { there is a lot of discussions with the other departments [to } \\
\text { solve] the problem [and] make it work" (System engineer) }\end{array}$ & $\begin{array}{l}\text { Representation } \\
\text { activity with } \\
\text { knowledge } \\
\text { sharing } \\
\text { activity }\end{array}$ \\
\hline & $\begin{array}{l}\text { Interdependency between products within the family: "I think } \\
\text { that the main problem is adapting to the various changes } \\
\text { because if it was only one product changing that would be } \\
\text { easier. But that combination [of product modules] makes it a bit } \\
\text { difficult to see." (User experience lead) }\end{array}$ & $\begin{array}{l}\text { Regular meetings with different departments were held in } \\
\text { order to better align the interdependency: "I was in the } \\
\text { feasibility studies, we had many meetings and long } \\
\text { discussions looking into these audio features from various } \\
\text { angles and you know trying to understand what are the } \\
\text { requirements, the team was not only the audio guys, lots of } \\
\text { people from the groups, and in the meetings we would present } \\
\text { our findings and I think that everybody knows what is going } \\
\text { on" (Digital signal processing engineer 2)" }\end{array}$ & $\begin{array}{l}\text { Knowledge } \\
\text { sharing project } \\
\text { activities }\end{array}$ \\
\hline & $\begin{array}{l}\text { High novelty of the utilized technology: "There is a lot of new } \\
\text { stuff in this product. There are } 10 \text { new audio features. (...) } \\
\text { usually the company already has issues when implementing only } \\
\text { one new feature, and now we are doing } 10 \text { so that is a } \\
\text { challenge" (Digital signal processing engineer 1) }\end{array}$ & $\begin{array}{l}\text { Pre-test studies: "We were ready to start the project before } \\
\text { the project [actually started]. We did a lot of studies in the } \\
\text { actual development phase. That is what is happening [before] } \\
\text { the company [gave the go ahead]" (System engineer) }\end{array}$ & $\begin{array}{l}\text { Representation } \\
\text { activities }\end{array}$ \\
\hline & $\begin{array}{l}\text { Modular product design with large variations between } \\
\text { individual products: "some headsets will have } 3 \text { microphones, } \\
\text { and some will only have one, so it's a completely different } \\
\text { process chain. (...) but what happens when you put a lot of new } \\
\text { features together that you never even try them in isolation (...) I } \\
\text { expect a lot of problems, honestly, because it's complicated and } \\
\text { every time you do something new." (Digital signal processing } \\
\text { engineer 2) }\end{array}$ & $\begin{array}{l}\text { Physical part testing: "We test for component failures or } \\
\text { sampler errors to make sure the components that are put into } \\
\text { the products are not defective and the performance is } \\
\text { expected and that the sampler is going well..." } \\
\text { (Manufacturing test engineer) }\end{array}$ & $\begin{array}{l}\text { Representation } \\
\text { project } \\
\text { activity }\end{array}$ \\
\hline $\begin{array}{l}\text { Organisational } \\
\text { uncertainty }\end{array}$ & $\begin{array}{l}\text { Project team collaboration: "Working with a new team is always } \\
\text { a challenge in a new project because (...) there are new people } \\
\text { coming in. You have to build a relationship, so I need to know } \\
\text { what strengths and weaknesses the mechanical guy has and the } \\
\text { hardware guys have, and some individuals in the team I deal } \\
\text { with more than others." (Industrialization project manager) }\end{array}$ & $\begin{array}{l}\text { Regular meetings to develop competencies within the PD } \\
\text { team as explained by the Product commercialization manager } \\
\text { 2: "[We have] regular weekly meetings that are more } \\
\text { information sharing. They tell what they had done and what } \\
\text { they are working on and what the status is." }\end{array}$ & $\begin{array}{l}\text { Knowledge } \\
\text { sharing project } \\
\text { activities }\end{array}$ \\
\hline
\end{tabular}


Time availability of internal personnel: "we had some

challenges in getting people the time to do the feasibility studies.

I was in the hardware group on the feasibility studies but the

hardware guy was very limited for time [because] he was in all

the projects" (System engineer)

Dependency between project team members in terms of

deliverables: "We have so many dependencies, deliverables

from other people, we order test features, we order equipment, we get deliverables from software, we get stuff from the

hardware team... we are so dependent on them."

(Manufacturing test engineer)

\section{Resource}

uncertainty
Need to develop new competencies in software development:

"we have an issue of product managers not having adequate skills to understand all these new digital services. This is making it very hard because on one hand you have people that do understand some of this (...) but on the other hand we are following our processes that are usually set up with very little room for experimenting" (Digital business developer)

Market Changing requirements of the product use: "the use case for the

uncertainty hardware department is more or less defined. But you can imagine a lot of different new use cases from the software perspective on top of the product where you can derive some information and maybe make some new applications." (Cloud project manager)
Regular alignment between team members regarding different

project parts with prioritisation of "which fire is higher"

Weekly meetings with between disciplines: "I was attending

a lot of these small technology meetings, regarding the

project. They were talking about features, what the market requires, what do we need to fulfil, this new generation, this new platform, so there was a lot of discussions. (...) I think we met every week. And [in addition] there were a lot of workshops in the different disciplines and then meeting again with this wrap up meeting. " (Product commercialization

\section{manager 1)}

Regular meetings with different departments for collaboration and alignment.

Knowledge sharing project activities

Identify product use cases: "First of all we had this very large quantitative data set from earlier research regarding call centric users, and then we decided to elaborate on that and look more into the details on the specific users we were aiming for on this project. So we recruited respondents in that area. We went to the US and to places in Europe, and we talked to agents there, and the ones that were going to use these headsets. (...) The aim was to elaborate on our findings and our assumptions about what it is to work in a call centre and what the daily life looked like (...) and also to validate our feature assumptions. " (User experience lead) Regular customer visits to identify "pain points" (Project manager 2): "he [project manager 2] likes to go out and talk to the user in the field and find what their pain points are, and that is something that he is able to do." (Manufacturing test engineer) 


\section{Discussion}

The aim of this work was to understand the relationship between four uncertainty types (Table 1) and three major project activities (Table 2) in NPD. To this end two cases were examined. Both cases captured NPD in a large high-tech company, and showed characteristics typical of this context i.e. the delivery of user experience (UX) and technical capability (Nurkka, Kujala, and Kemppainen 2009) via a Stage-Gate type process (Ulrich and Eppinger 2003), and experiencing challenges ranging from the fuzzy front end to production planning (Andreasen, Thorp Hansen, and Cash 2015). Further, saturation was achieved in both cases, and results were triangulated across cases (Yin 2018). Thus, the reported cases provide a robust basis for developing insights related to NPD practice.

The empirical work shows four main findings, suggesting specific links between individual uncertainty types and project activities as follows. The findings link technical uncertainty and representation activity; organisational uncertainty and knowledge sharing activity; resource uncertainty and knowledge sharing; and market uncertainty and information activity. This section discusses the individual findings in more detail in the light of existing theory in the engineering design and management literature.

The first main finding was the connection between technical uncertainty and representation activity. More specifically, this type of activity was observed with regard to computational simulation and physical prototyping of the product as well as product part integration. Representational prototyping played a critical role in both cases. While this link has been suggested in the literature (Hooge et al. 2016; Gerber and Carroll 2012; Scaife and Rogers 1996) this study confirms and extends understanding in this area. Specifically, this link is elaborated by suggesting a degree of synergy between representation activity and supporting knowledge sharing activity in a secondary role. 
For example, when technical uncertainty was connected to technical complexity in Case $\mathrm{B}$, a further response (beyond representation) included knowledge sharing between the different development team members. This connection has also been eluded to in the NPD literature (Verworn, Herstatt, and Nagahira 2008). However, the results of this study suggest the existence of a primary link between technical uncertainty and representation activity, which may be complemented by a secondary link with knowledge sharing activity when technical complexity is high.

The second main finding connects organisational uncertainty to knowledge sharing activity in the form of meetings to align activities, priorities, and resources across departments and team members. The literature on organisational uncertainty in NPD is still relatively immature and connections to specific project activities have thus far not been described. Instead, existing descriptions have pointed to almost all types of response (Frishammar, Floren, and Wincent 2011). This research thus contributes to the engineering design literature by offering the first identification of a single major project activity response associated with organisational uncertainty in the form of knowledge sharing activities.

The third main finding connects resource uncertainty with knowledge sharing activities. While the observations of resource uncertainty align with some prior works in the innovation area (O’Connor and Rice 2013), these are extended by characterising a number of linked patterns in knowledge sharing activities in the engineering design context. Specifically, the results show multi-modal knowledge exchange in terms of meetings, and alignment of expectations with the supplier to clarify delivery logistics and to align expectations on product part functionality. This aligns with prior insights surrounding barriers to knowledge sharing in design (Kleinsmann and Valkenburg 2008). As with organisational uncertainty, resource uncertainty has not been 
characterised with respect to specific project activity responses. As such, this research offers an important contribution by identifying knowledge sharing activities as a response to resource uncertainty in engineering design.

The fourth main finding connects market uncertainty with information activity. Again, the observations of market uncertainty align with descriptions in the literature (Song, Jinhong, and Di Benedetto 2001; Unger and Eppinger 2011). Information activity was related to research on consumers and competitors in both cases. Previous research has eluded to this connection (Christensen and Ball 2017) as the concept of market uncertainty is well established and widely explored in the NPD and innovation management literatures. Thus, this research confirms and further extends these insights by showing that this information activity is focused on information seeking about consumers and competitors in the engineering design context.

The main findings are summarised in a number of propositional relationships (Figure 1) detailing the links between four uncertainty types and three project activities. Together, these findings confirm prior links between uncertainty and project activity for market uncertainty; substantially elaborate the link between technical uncertainty and representation activity, which is coupled with knowledge sharing activity when technical complexity is present; and offer new characterisations of project activity responses to organisational uncertainty and resource uncertainty.

The propositional relationships outlined in Figure 1 take a first step towards addressing the two major needs of engineering designers when dealing with uncertainty in NPD i.e. uncertainty identification and appropriate response (Kreye et al. 2020). Specifically, this research elucidates the diversified view of uncertainty types from the management literature in the engineering design context (O’Connor and Rice 2013), providing a foundation for NPD team leaders in better identifying the specific 
uncertainty types encountered. Further, by describing characteristic relationships between these uncertainty types and specific project activities this work offers initial guidance for selecting appropriate responses to uncertainty, as well as a basis for wider, quantitative, evaluation of these links. In particular, this extends and elaborates prior descriptions of varying responses to specific uncertainty types (Gassmann and Schweitzer 2014; Yao, Jiang, and Liu 2013).

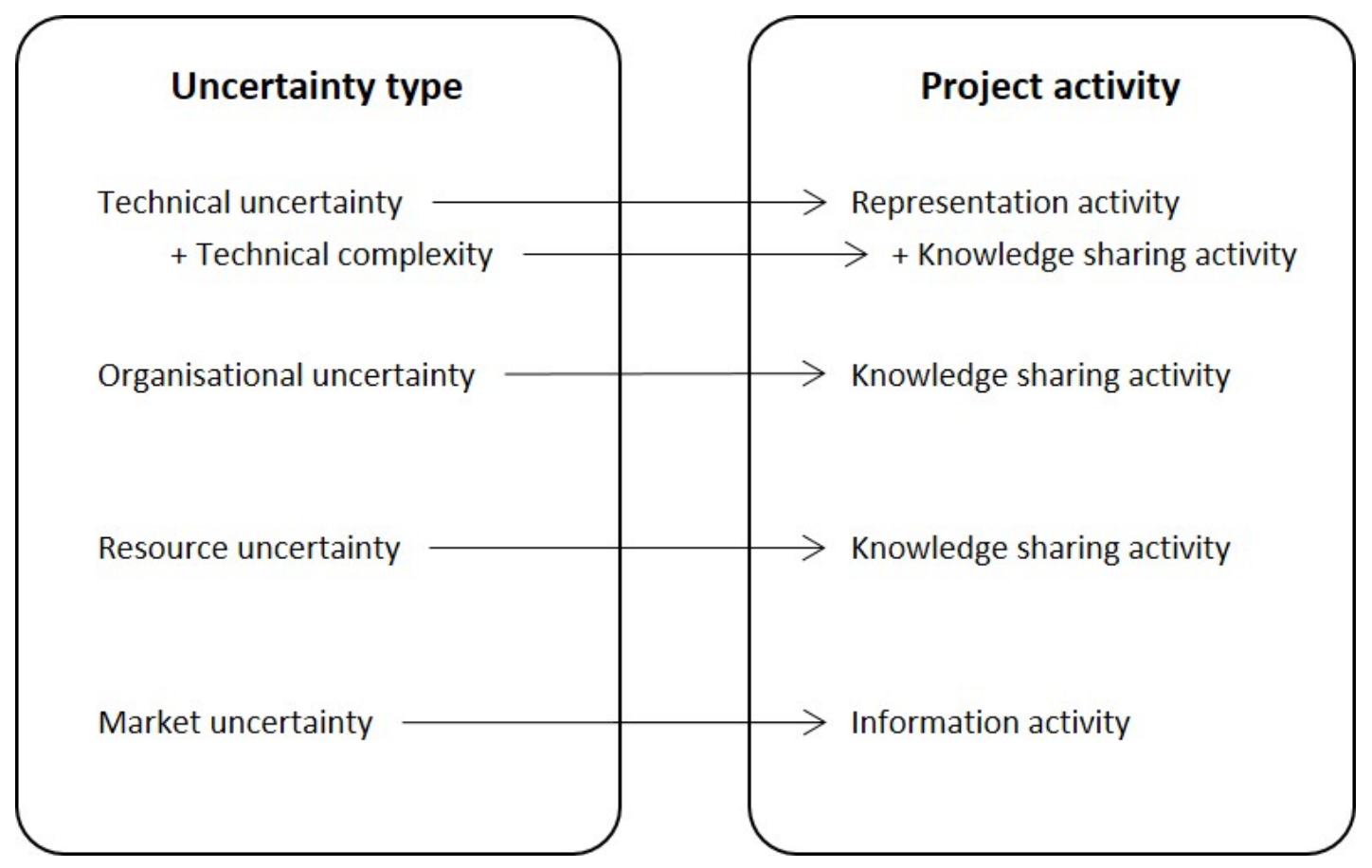

Figure 1: Propositional relationships between four uncertainty types (technical uncertainty, organisational uncertainty, resource uncertainty and market uncertainty) and three project activities (information activity, knowledge sharing activity and representation)

\section{Limitations and further work}

Given the qualitative nature of this research, the relationships described in Figure 1 must be considered as propositional. As such, this research has important implications for future work. First, future work needs to confirm the proposed relationships between uncertainty types and project responses through more quantitative studies (Handfield and Melnyk 1998). Here, experimental studies could investigate the behavioural 
implications of the proposed relationships, while survey studies could explore the wider generalisability of the connections across engineering design contexts. Second, future work needs to provide further depth on the varying nature of the responses, and refine their conceptualisation with respect to other drivers of project activity (Wacker 2008). For example, this research showed that technical complexity is linked to knowledge sharing activity and can in combination with representation activity reduce technical uncertainty. This is an interesting emergent finding and links to long-standing discussions that connect uncertainty and complexity. Hence this work provides an important first step, which requires further quantitative and qualitative investigation in order to understand the generality of the identified relationships (Cash 2018; Handfield and Melnyk 1998). We report initial work in this direction in Lasso et al. (2020).

\section{Implications}

This research has important implications for engineering designers as it enables NPD team leaders to focus on facilitating the project activities most critical to the specific uncertainty type experienced by the NPD team. The proposed relationships (Figure 1) can offer guidance in this decision-making process and shows the importance of responding to the specific nature of critical NPD situations. Specifically, when engaging in critical NPD situations with high technical novelty and hence high levels of technical uncertainty, managers might consider investing in supporting diverse representation activities including varied simulation and feasibility studies. When engaging in critical NPD situations with high organisational uncertainty through, for example, a large number of involved individuals and disciplines, team leaders might consider focusing on promoting diverse knowledge sharing activities, particularly in the project set-up. When engaging in critical NPD situations with high resource uncertainty, for example, when there is a need for external supplier participation, engineers might consider 
developing additional supplier focused knowledge sharing activities. When engaging in critical NPD situations with high market uncertainty, engineers might consider investing in information activity, in terms of research focusing on consumers and competitors.

\section{Conclusions}

This research set out to investigate: How do uncertainty types drive the selection of project activities in NPD? Presenting insights from two in-depth case studies, the findings show how four uncertainty types are respectively connected to specific project activities. These are connected in a set of propositional relationships: technical uncertainty links to representation activity, organisational uncertainty links to knowledge sharing activity, resource uncertainty links to knowledge sharing activity, and market uncertainty links to information activity. This research contributes to the engineering design literature by offering a number of propositional relationships capturing distinct connections between uncertainty types and project activities. Based on strong confirmatory evidence for the translation of uncertainty types from the innovation literature to the engineering design context (O'Connor and Rice 2013; Song, Jinhong, and Di Benedetto 2001), as well as the further development of frameworks describing design project activities (Cash and Kreye 2017, 2018). Thus, this research is firmly rooted in existing theory and provides novel contributions to the engineering design literature, as well as implications for practice and future research.

\section{References}

Andreasen, M M, C Thorp Hansen, and P Cash. 2015. Conceptual Design: Interpretations, Mindset and Models. Conceptual Design: Interpretations, Mindset and Models. Springer. https://doi.org/10.1007/978-3-319-19839-2.

Bedny, G Z, and S R Harris. 2005. "The Systemic-Structural Theory of Activity: Applications to the Study of Human Work." Mind, Culture, and Activity 12 (2): 12847.

Behrens, J. 2016. "A Lack of Insight: An Experimental Analysis of R\&D Managers' Decision Making in Innovation Portfolio Management." Creativity and Innovation 
Management 25 (2): 239-50. https://doi.org/10.1111/caim.12157.

Benavides, E M, and O Lara-Rapp. 2019. "Ideal Output for a Robust Conceptual Design Process." Journal of Engineering Design 30 (4-5): 103-54. https://doi.org/10.1080/09544828.2019.1598552.

Bennett, N, and J Lemoine. 2014. "What VUCA Really Means for You." Harvard Business Review 92 (1/2): 1.

Blauth, M, R Mauer, and M Brettel. 2014. "Fostering Creativity in New Product Development through Entrepreneurial Decision Making." Creativity and Innovation Management 23 (4): 495-509. https://doi.org/10.1111/caim.12094.

Borgianni, Y, G Cascini, and F Rotini. 2018. "Investigating the Future of the Fuzzy Front End: Towards a Change of Paradigm in the Very Early Design Phases?" Journal of Engineering Design 29 (11): 644-64. https://doi.org/10.1080/09544828.2018.1520971.

Carleton, T, W Cockayne, and L Leifer. 2007. "An Exploratory Study about the Role of Ambiguity During Complex Problem Solving." In AAAI Spring Symposium: Creative Intelligent Systems'08, 1-6. Stanford, Califormia, USA.

Cash, P. 2018. "Developing Theory-Driven Design Research." Design Studies 56 (May): 84-119. https://doi.org/10.1016/j.destud.2018.03.002.

Cash, P, B Hicks, and S Culley. 2015. "Activity Theory as a Means for Multi-Scale Analysis of the Engineering Design Process: A Protocol Study of Design in Practice." Design $\quad$ Studies 38 (May): $1-32$. https://doi.org/10.1016/j.destud.2015.02.001.

Cash, P, and M E Kreye. 2017. "Uncertainty Driven Action (UDA) Model: A Foundation for Unifying Perspectives on Design Activity.” Design Science 3 (e26): 1-41.

Cash, P, and M E Kreye. 2018. "Exploring Uncertainty Perception as a Driver of Design Activity." Design Studies 54 (January): 50-79.

Cash, P, S Skec, and M Storga. 2019. "The Dynamics of Design: Exploring Heterogeneity in Meso-Scale Team Processes." Design Studies 64 (September): 124-53.

Chalupnik, M J, D C Wynn, and P J Clarkson. 2013. "Comparison of Ilities for Protection against Uncertainty in System Design.” Journal of Engineering Design 24 (12): 814-29. https://doi.org/10.1080/09544828.2013.851783.

Christensen, B T, and L J Ball. 2017. "Fluctuating Epistemic Uncertainty in a Design Team as a Metacognitive Driver for Creative Cognitive Processes." In Analysing Design Thinking: Studies of Cross-Cultural Co-Creation, edited by B T Christensen, L J Ball, and K Halskov, 249-70. CRC Press.

Christensen, B T, and C D Schunn. 2009. "The Role and Impact of Mental Simulation in Design." IEEE Transactions on Engineering Management 344: 327-44. https://doi.org/10.1002/acp.

Davenport, T H, D W De Long, and M C Beers. 2014. "Building Successful Knowledge Management Projects." Sloan Management Review 39 (2): 43-57.

Dempster, A M. 2006. "Managing Uncertainty in Creative Industries: Lessons from Jerry Springer the Opera." Creativity and Innovation Management 15 (3): 224-33. https://doi.org/10.1111/j.1467-8691.2006.00391.x.

Eisenhardt, K M. 1989. "Building Theories from Case Study Research." Academy of Management Review 14 (4): 532-50.

Eisenhardt, K M, and M E Graebner. 2007. "Theory Building from Cases: Opportunities and Challenges." Academy of Management Journal 50 (1): 25-32.

Eisenhart, M. 2009. "Generalization from Qualitative Inquiry." In Generalizing from Educational Research: Beyond Qualitative and Quantitative Polarization, edited by K Erickan and W-M Roth, 51-66. 
Evanschitzky, H, M Eisend, R J Calantone, and Y Jiang. 2012. "Success Factors of Product Innovation: An Updated Meta-Analysis." Journal of Product Innovation Management 29: 21-37. https://doi.org/10.1111/j.1540-5885.2012.00964.x.

Fixson, S K, D Khachatryan, and W Lee. 2017. "Technological Uncertainty and Firm Boundaries: The Moderating Effect of Knowledge Modularity." IEEE Transactions on Engineering Management 64 (1): 16-28. https://doi.org/10.1109/TEM.2016.2638847.

Fox, J, R Gann, A Shur, L Von Glahn, and B Zaas. 1998. "Process Uncertainty: A New Dimension for New Product Development." Engineering Management Journal 10 (3): 19-27. https://doi.org/10.1080/10429247.1998.11414992.

Frishammar, J, H Floren, and J Wincent. 2011. "Beyond Managing Uncertainty: Insights From Studying Equivocality in the Fuzzy Front End of Product and Process Innovation Projects." IEEE Transactions on Engineering Management 58 (3): 55163. https://doi.org/10.1109/tem.2010.2095017.

Galbraith, J R. 1974. "Organization Design: An Information Processing View." Interfaces. https://doi.org/10.1287/inte.4.3.28.

Gassmann, O, and F Schweitzer. 2014. Management of the Fuzzy Front End of Innovation. Management of the Fuzzy Front End of Innovation. Cham, Switzerland: Springer International Publishing. https://doi.org/10.1007/978-3-319-01056-4.

Gerber, E, and M Carroll. 2012. "The Psychological Experience of Prototyping." Design Studies 33 (1): 64-84. https://doi.org/10.1016/j.destud.2011.06.005.

Gibbert, M, W Ruigrok, and B Wicki. 2008. "WHAT PASSES AS A RIGOROUS CASE STUDY?” Strategic Management Journal 29 (13): 1465-74. https://doi.org/10.1002/smj.

Handfield, R B, and S A Melnyk. 1998. "The Scientific Theory-Building Process: A Primer Using the Case of TQM." Journal of Operations Management 16 (4): 32139. https://doi.org/10.1016/S0272-6963(98)00017-5.

Herstatt, C, B Verworn, and A Nagahira. 2004. "Reducing Project Related Uncertainty in the 'Fuzzy Front End' of Innovation: A Comparison of German and Japanese Product Innovation Projects." International Journal of Product Development 1 (1): 43-65. https://doi.org/10.1504/IJPD.2004.004890.

Hooge, S, O Kokshagina, P Le Masson, K Levillain, B Weil, V Fabreguettes, and N Popiolek. 2016. "Gambling versus Designing: Organizing for the Design of the Probability Space in the Energy Sector." Creativity and Innovation Management 25 (4): 464-83. https://doi.org/10.1111/caim.12178.

Hult, G T M, D J Ketchen, and S F Slater. 2004. "Information Processing, Knowledge Development, and Strategic Supply Chain Performance." Academy of Management Journal 47 (2): 241-53.

Jenab, K, A Sarfaraz, and M T Ameli. 2013. “A Conceptual Design Selection Model Considering Conflict Resolution." Journal of Engineering Design 24 (4): 293-304. https://doi.org/10.1080/09544828.2012.728203.

Johnson, W H A. 2007. "Managing Uncertainty in Innovation: The Applicability of Both Real Options and Path Dependency Theory." Creativity and Innovation Management 16 (3): 274-81. https://doi.org/10.1111/j.1467-8691.2007.00436.x.

Kleinsmann, M, and R Valkenburg. 2008. "Barriers and Enablers for Creating Shared Understanding in Co-Design Projects." Design Studies 29 (4): 369-86. https://doi.org/10.1016/j.destud.2008.03.003.

Kokshagina, O, P Le Masson, B Weil, and P Cogez. 2016. "Portfolio Management in Double Unknown Situations: Technological Platforms and the Role of CrossApplication Managers." Creativity and Innovation Management 25 (2): 270-91. 
https://doi.org/10.1111/caim.12121.

Kreye, M E, P Cash, P Parraguez, and A M Maier. 2020. "Dynamism in Complex Engineering: Explaining Uncertainty Growth through Uncertainty Masking." IEEE Transactions on Engineering Management, IN PRESS.

Kreye, M E, Y M Goh, L B Newnes, and P Goodwin. 2012. "Approaches of Displaying Information to Assist Decisions under Uncertainty." Omega - International Journal of Management Science 40 (6): 682-92.

Kreye, M E, L B Newnes, and Y M Goh. 2013. "Information Availability at the Competitive Bidding Stage for Service." Journal of Manufacturing Technology Management 24 (7): 976-97.

Lasso, S, P Cash, J Daalhuizen, and M E Kreye. 2020. "Uncertainty and Activity Selection in New Product Development: An Experimental Study." IEEE Transactions on Engineering Management, IN PRESS.

MacCormack, A, and R Verganti. 2003. "Managing the Sources of Uncertainty: Matching Process and Context in Software Development." Journal Article. Journal of Product Innovation Management 20 (3): 217-32. https://doi.org/10.1111/15405885.2003004.

Mackey, R. 1992. "Translating Vision into Reality: The Role of the Strategic Leader." Carlisle, PA, USA.

Marion, T J, J H Friar, and T W Simpson. 2012. "New Product Development Practices and Early-Stage Firms: Two In-Depth Case Studies." Journal of Product Innovation Management 29 (4): 639-54. https://doi.org/10.1111/j.1540-5885.2012.00930.x.

Miles, M B, A M Huberman, and J Saldana. 2014. Qualitative Data Analysis: A Methods Sourcebook. 3rd ed. New York, USA: SAGE Publications.

Noor, K. 2008. "Case Study: A Strategic Research Methodology Khairul Baharein Mohd Noor." American Journal of Applied Sciences 5 (11): 1602-4. https://doi.org/10.3844/ajassp.2008.1602.1604.

Nurkka, P, S Kujala, and K Kemppainen. 2009. "Capturing Users' Perceptions of Valuable Experience and Meaning." Journal of Engineering Design 20 (5): 449-65. https://doi.org/10.1080/09544820903158835.

O'Connor, G C, and M P Rice. 2013. "A Comprehensive Model of Uncertainty Associated with Radical Innovation." Journal Article. Journal of Product Innovation Management 30 (SUPPL 1): 2-18. https://doi.org/10.1111/jpim.12060.

Onwuegbuzie, A J, and K M T Collins. 2007. "A Typology of Mixed Methods Sampling Designs in Social Science Research." The Qualitative Report 12 (2): 281-316. https://doi.org/10.1177/1558689807299526.

Renzi, C, F Leali, and L Di Angelo. 2017. "A Review on Decision-Making Methods in Engineering Design for the Automotive Industry." Journal of Engineering Design 28 (2): 118-43. https://doi.org/10.1080/09544828.2016.1274720.

Robson, C, and K McCartan. 2011. Real World Research. 4th ed. Chichester: Wiley. http://sfx4.exlibrisgroup.com:9003/bath?sid=google.

Sandelowski, M. 1995. "Sample Size in Qualitative Research." Research in Nursing \& Health 18 (2): 179-83. https://doi.org/10.1002/nur.4770180211.

Scaife, M, and Y Rogers. 1996. "External Cognition: How Do Graphical Representations Work?" International Journal of Human-Computer Studies 45 (2): 185-213. http://www.sciencedirect.com/science/article/pii/S1071581996900488.

Schmitt, S O, M Scheitza, and P Groche. 2015. "A Model for Improving the Applicability of Design Methodologies to Mechanical Engineering Design Routines." Journal of $\begin{array}{llll}\text { Engineering } & \text { Design } & 26 & (10-12):\end{array}$ https://doi.org/10.1080/09544828.2015.1048198. 
Sicotte, H, and M Bourgault. 2008. "Dimensions of Uncertainty and Their Moderating Effect on New Product Development Project Performance." R\&D Management 38 (5): 468-479. https://doi.org/10.1111/j.1467-9310.2008.00531.x.

Sim, S K, and A H B Duffy. 2003. "Towards an Ontology of Generic Engineering Design Activities." Research in Engineering Design 14 (4): 200-223. http://link.springer.com/article/10.1007/s00163-003-0037-1.

Song, M, X Jinhong, and C A Di Benedetto. 2001. "Message and Source Factors, Market Uncertainty, and Extrafunctional Information Processing: Hypotheses and Empirical Evidence." IEEE Transactions on Engineering Management 48 (2): 223-38. https://doi.org/10.1109/17.922480.

Stone, T, S K Choi, and H Amarchinta. 2013. "Structural Model Refinement under Uncertainty Using Decision-Maker Preferences." Journal of Engineering Design 24 (9): 640-61. https://doi.org/10.1080/09544828.2013.824560.

Storga, M, M M Andreasen, and D Marjanovic. 2010. "The Design Ontology: Foundation for the Design Knowledge Exchange and Management." Journal of Engineering Design 21 (4): 427-54. https://doi.org/10.1080/09544820802322557.

Styhre, A, L Wikmalm, S Olilla, and J Roth. 2010. "Garbage-Can Decision Making and the Accommodation of Uncertainty in New Drug Development Work." Creativity and Innovation Management 19 (2): 134-46. https://doi.org/10.1111/j.14678691.2010.00551.x.

Suss, S, and V Thomson. 2012. "Optimal Design Processes under Uncertainty and Reciprocal Dependency." Journal of Engineering Design 23 (10-11): 826-48. https://doi.org/10.1080/09544828.2012.704546.

Ulrich, K T, and S D Eppinger. 2003. Product Design and Development. Vol. 5th. New York, USA: MvGraw-Hill. http://sfx4.exlibrisgroup.com:9003/bath?sid=google.

Unger, D, and S Eppinger. 2011. "Improving Product Development Process Design: A Method for Managing Information Flows, Risks, and Iterations." Journal of Engineering Design $22 \quad$ (10): 689-99. https://doi.org/10.1080/09544828.2010.524886.

Verworn, B, C Herstatt, and A Nagahira. 2008. "The Fuzzy Front End of Japanese New Product Development Projects: Impact on Success and Differences between Incremental and Radical Projects." $R \& D$ Management 38 (1): 1-19. https://doi.org/10.1111/j.1467-9310.2007.00492.x.

Wacker, J G. 2008. "A Conceptual Understanding of Requirements for Theory-Building Research: Guidelines for Scientific Theory Building." Journal of Supply Chain Management 44 (3): 5-15. https://doi.org/10.1111/j.1745-493X.2008.00062.x.

Wasiak, J, B Hicks, L Newnes, C Loftus, A Dong, and L Burrow. 2011. "Managing by E-Mail: What e-Mail Can Do for Engineering Project Management." IEEE Transactions on Engineering Management 58 (3): 445-56. https://doi.org/10.1109/TEM.2010.2090160.

Wiener, M. 2018. "Open Foresight: The Influence of Organizational Context." Creativity and Innovation Management 27 (1): 56-68. https://doi.org/10.1111/caim.12238.

Wiltschnig, S, B T Christensen, and L J Ball. 2013. "Collaborative Problem-Solution CoEvolution in Creative Design." Design Studies 34 (5): 515-42. https://doi.org/10.1016/j.destud.2013.01.002.

Yao, T, B Jiang, and H Liu. 2013. "Impact of Economic and Technical Uncertainties on Dynamic New Product Development." IEEE Transactions on Engineering Management 60 (1): 157-68. https://doi.org/10.1109/TEM.2012.2187061.

Yin, R K. 2018. Case Study Research and Applications: Design and Methods. 6th ed. Los Angeles, CA, USA: Sage Publications Inc. 
Zimmermann, M, S Königs, C Niemeyer, J Fender, C Zeherbauer, R Vitale, and M Wahle. 2017. "On the Design of Large Systems Subject to Uncertainty." Journal of Engineering Design 28 https://doi.org/10.1080/09544828.2017.1303664.

(4): $\quad 233-54$. 